\title{
An Overview of the Right to Strike in Nigeria and Some Selected Jurisdictions
}

\author{
Bokolo P. S. Giame ${ }^{1}$, Ufuoma V. Awhefeada ${ }^{2 *}$, Omerionwan K. Edu ${ }^{2}$ \\ ${ }^{1}$ Faculty of Law, Edwin Clarke University, Kiagbodo, Nigeria \\ ${ }^{2}$ Faculty of Law, Delta State University, Oleh Campus, Delta State, Nigeria \\ Email: gpgiame@yahoo.com, ^fuoma2002@yahoo.com, ^awhefeadau@gmail.com, kingseduperfection@yahoo.com
}

How to cite this paper: Giame, B. P. S., Awhefeada, U. V., \& Edu, O. K. (2020). An Overview of the Right to Strike in Nigeria and Some Selected Jurisdictions. Beijing Law Review, 11, 464-488.

https://doi.org/10.4236/blr.2020.112029

Received: March 2, 2020

Accepted: May 5, 2020

Published: May 8, 2020

Copyright (c) 2020 by author(s) and Scientific Research Publishing Inc. This work is licensed under the Creative Commons Attribution International License (CC BY 4.0).

http://creativecommons.org/licenses/by/4.0/

(c) (i) Open Access

\begin{abstract}
This paper examines the right to strike in Nigeria and seeks to establish whether Nigerian workers under the various enactments, which purports to prohibit and criminalize strike action by workers amounts to a violation of their right to strike. The paper further examines the right to strike in some selected jurisdictions. The relevant constitutional provisions entrenching the fundamental right of freedom of association as well as the provisions of other national and international legal instruments which guarantee the right to strike as well as the right to collectively bargain on behalf of trade unions are discussed in detail. The paper reviews the law relating to industrial disputes in Nigeria and finds that it has remained oppressive on workers. In spite of this, workers have continued to use strikes in expressing their grievances. The paper argues for the express entrenchment of the right to strike in the Constitution and other relevant laws as obtainable in countries such as South Africa and Ghana. The doctrinal research method is employed in this paper.
\end{abstract}

\section{Keywords}

The Right to Strike, The Constitution of the Federal Republic of Nigeria 1999 (as Amended), Trade Disputes Act, Selected Jurisdictions

\section{Introduction}

Strike as a means by which employees exert pressure on their employers to acceding to their demands has a long standing history. Essentially, this paper seeks to critically examine the laws regulating strike actions in Nigeria; this is to ascertain whether indeed there exists a right to strike. The etymology of the term "strike" is considered from the standpoint of jurists, judicial decisions as well as statutory provisions. This paper also takes a foray into some selected jurisdic- 
tions such as South Africa, the Republic of Ghana and the United Kingdom with regards to the regulation of Strikes. The doctrinal research method, which basically involves research into law as it is provided for by relevant legislation is employed. The paper is made up of ten segments. It opens with an introduction, which is followed by an overview of strikes in history as well as an examination of the salient causes of strikes followed by an examination of the meaning of strike. The fourth segment deals with the freedom of association and collective bargaining, followed by an analysis of the right to strike in Nigeria. The next two segments focus in detail on the right to strike under the Nigerian Constitution and then under other domestic legislations. The eight segments involve an analysis of the position of the law regulating strikes in South Africa, the United Kingdom and the Republic of Ghana. This is followed by recommendations drawing heavily from what is obtainable in the laws of the selected jurisdictions. Finally, the last segment is the conclusion wherein it is reiterated that the right interpretation to adopt is that there is the right to strike in Nigeria that has not been extinguished by the extant legislation; however, there is need to have the right to strike expressly and lucidly spelt out in the constitution which is the fundamental law of the land.

\section{Overview and Causes of Strikes}

It is on record that the first known strike or workers uprising was embarked by the Artisans of the Royal Necropolis at Deir el-Medina on November 141152 BC under the rule of Pharaoh Ramses III in ancient Egypt (Romer, 1984). Their core demand was an increase in wages and improvement on other working conditions. The impact of the strike was so great that the authorities had never seen nor heard of any such rebellion. At the end, the authorities had to give in to some of the demands of the workers especially rise in their wages (Abuza, 2016). Retrospectively, trade unions and industrial action began to surface in work places when employees were faced with harsh work conditions and exploitation by their employers during the industrial revolution in Britain in the eighteenth and nineteenth centuries respectively. Workers began to combine and pull their strength into a concerted group to take action to improve on their terms and conditions of employment and work environment. The employers were averse to the workers formation of petty unions and any resort to concerted action to improve their terms and conditions of work. To them this was a dangerous trend that must not be allowed to be sustained as they saw these as harmful to industrial peace and development (Chianu, 2004).

In the United Kingdom (England) Strike was first recorded in 1768, when sailors in support of demonstrations in London, struck or removed the topgallant sails of merchants ship at the Port, thereby incapacitating or crippling the ship. Also, during the American Economic depression of 1937, there were over 4740 recorded labour related strikes (Modern Labour Movement).

In Nigeria, the first strike was recorded on June 21, 1945, after failure of protracted presentations to the government for salary increase to meet the very high 
increase in cost of living. About 150,000 (One Hundred and Fifty Thousand) Clerical and Non-Clerical workers in the Nigeria Civil Service came together in a general strike of all Government Departments (Padmore, 1945). Since then, the incidence of strike in Nigeria has been on the increase and unabated. Most strikes are undertaken by labour unions when there is a breakdown or deadlock of negotiations or collective bargaining between employees and employers. The main purpose of collective bargaining is to obtain a binding contract, an agreement between the Union and Management which may include a no-strike clause which prevents strikes, or penalises the union and/or the workers if they walk out while the negotiation is on and the contract is still in force.

Strike is usually reserved as the last weapon during negotiations between Management and the Union, which may occur just before; or immediately after, the negotiation fails. In Union Bank of Nigeria PIc v. Edet (1993), Uwaifo (JCA) as he was, had this to say with regards to the right to strike and ensuring that collective agreements are enforced.

It appears that whenever an employer ignores or breaches a term of that agreement resort could only be had, if at all, to negotiation between the union and the employer and ultimately to a strike should the need arise and it be appropriate (Ibid).

Industrial disputes arise due to conflict or disagreement in industrial relations. The term "Industrial Relation" involves various aspects of interactions between the employer and the employees, in this relationship, whenever there is a collusion of interest, it usually results in dissatisfaction of either of the parties involved and hence lead to industrial disputes or conflicts. These disputes may take various forms such as protests, strikes, demonstrations, lock-outs etcetera. There are undoubtedly several reasons behind industrial conflicts. Some are related to the work environment while others are basically outside of the work environment (Otobo, 1987). It is because of this that the International Labour Organization's Committee on Freedom of Association argue that the right to strike is one of the potent means open to workers union for the promotion, protection and preservation of their economic and social interests within and outside the work place (ILO, 1985).

It is important to note that the Committee of Experts on the Application of Conventions and Recommendations has expressed the view that:

The protection of these interests does not only have to do with ensuring better working conditions and aggressively pursuing collective demands of the Union but also with seeking solutions to economic and social policy questions and to labour problems of any kind which may directly affect and the workers (ILC, 1983).

Generally, the inability of parties to settle their internal disputes or conflicts is the major cause of industrial strike. This may arise because of one or more of the reasons enumerated below: 
First is the failure to honour Collective Agreements reached by the parties after negotiations. On many occasions in Nigeria, trade unions have gone on strike for failure of government to honour agreements entered and executed by the parties. For example, the Academic Staff Union of Universities (ASUU) has embarked on several strikes since 2002 because of the inability of the Federal Government to honour their part of agreement on proper funding of the Educational Sector since 2001.

Second is the demand for salary and wage increase. Labour has been on a continuous move to close up the gap between income and economic realities because of inflation, poor infrastructure and social amenities. They have constantly insisted on increase in salaries and allowances. Recently, the Nigeria Labour Congress (NLC) went on strike asking for increase in the minimum wage from 18,000 to 30,000 as a sustainable income wage.

Third is that obnoxious policies employer come up with, which negatively affect the fundamental rights of the employees. Policies which stipulate for instance that couples working in the same institution cannot remain together, one of the spouses must go on voluntary retirement or both be asked to leave the institution. This is most common in the private sector.

Fourth, the demand for improved labour welfare and other benefits is another cause of strikes. Most times employees go on strike because of agitation for improved work conditions such as provision of canteen, rest recreation, accommodation facilities, travelling allowances, health care facilities etcetera.

Fifth, the denial of opportunity to the worker to satisfy their basic right for self-expression, personal achievement and betterment may also result in labour problems. For example, where employees are denied training or study leave with pay. The difference in compensation and conditions of service for workers in the same institution is also one of the causes of strikes. This has been a major cause of strike in the Tertiary Institutions in Nigeria. For example, the Federal Government of Nigeria approved a total of N23 billion earned allowance for federal Universities out of which only $2 \%$ was for the teaching and non-teaching staff of the University of Lagos (Iyabo, 2019). This has caused bad blood within the system as the unfavoured association has continuously frowned at the discrepancy or disparity in the benefits accruing to the academic staff, even though they work in the same institution and environment.

\section{Meaning of Strike}

There appears to be no exact definition of the term "strike." An examination of the definitions in Dictionaries and relevant Statutes in Nigeria and other jurisdictions such as United Kingdom (Britain), South Africa, Ghana and Judicial authorities all show that there is no common definition of the term strike. The Black's Law Dictionary defines "strike" as "an organized cessation or slowdown of work by employees to compel the employer to meet the employee's demands" (Garner, 2014). 
Whereas the New Britannica-Webster Dictionary defines it as:

1) Work stoppage by a body of workers to force an employer to comply with demands.

2) A temporary stoppage of activities in protest against an act or condition (Webster, 1993).

Section 48 (1) of the Trade Disputes Act (TDA) defines strike as follows:

Strike means the cessation of work by a body of persons employed acting in combination or a concerted refusal under a common understanding of any number of persons employed to continue to work for an employer in consequence of a dispute, done as a means of compelling their employer or any person or body of persons employed, or to aid other workers in compelling their employer or any person or body of persons employed, to accept or not to accept terms of employment and physical conditions of work (TDA, 2004).

And in this definition:

1) "Cessation of work" includes working at speed less than usual or with less than usual efficiency; and

2) "Refusal to continue to work" includes a refusal to work at usual speed or with usual efficiency.

In South Africa, the term strike is defined as:

The partial or complete concerted refusal to work, or the obstruction of work, by persons who are or who have been employed by the same employer or by different employers, for the purpose of remedying a grievance or resolving a dispute in respect of any matter of mutual interest between employer and employees (LRA, 2002).

Whereas in Ghana strike means:

Any action by two or more workers acting in concert which is intended by them to restrict in any way the service they normally provide to the employer or diminish the output of such service with a view to applying coercive pressure upon the employer and includes sympathy strike and those activities commonly called a work-to-rule, a go slow or a sit down strike (Labour Act of Ghana, 2003).

On the other hand, the Employment Rights Act of Britain defines strike as:

1) The cessation of work by a body of employed persons acting in combination or

2) A concerted refusal by a body of employed persons to refuse to work for an employer in consequence of a dispute, done as a means of compelling their employer to accept or not to accept terms and conditions of or affecting employment (ERA, 1996).

Moving or digressing slightly away from statute, judicial definition of the meaning of strike has further reaffirmed the inherent insistencies and differences 
as to the true meaning of strike. Lord Denning M.R. in tramp Shipping Corporation v. Greenwich Marine Inc. (1975) defined strike as follows:

Strike is a concerted stoppage of work by men, done... with a view to improving their wages or condition of employment, or giving vent to a grievance or making a protest about something, or otherwise supporting or sympathizing with other workmen in such endeavour.

Apparently from the judicial view point as espoused by Lord Denning, strike includes protest over wages and other conditions of employment as well as sympathy strike.

Looking at the various definitions closely, it appears that Section 48 (1) of the Trade Disputes Act is more comprehensive and exhaustive except for the fact it did not include the right to protest as defined by Lord Denning in Tramp's case.

\section{Freedom of Association and Collective Bargaining}

The right to freedom of association and collective bargaining is today well recognized in Nigeria and internationally. The Constitution of the Federal Republic of Nigeria 1999, Section 40, guarantees its citizens to freely join any political party or trade union in order to protect its interest. Similarly, the International Labour Organization (ILO) and Article 20 of the Universal Declaration of $\mathrm{Hu}$ man Rights 1948 also recognize the freedom of association by workers. Both statutes up hold the tenet that workers should be free to join any trade union without coercion by their employers or any authority. Collective bargaining on the other is the means through which employees and employers freely negotiate terms and conditions of their work.

Without collective bargaining through the union, each worker would be expected to negotiate independently with his employer and thereby create variegated work conditions within a particular work environment. It is a well recognized fundamental right of the union. Strictly speaking, collective bargaining will be useless and ineffective without the freedom of association. The liberty to freely negotiate and hold sway the power of the employer is only through the collective solidarity of the workers as a union.

Freedom of association and collective bargaining are concomitant rights of the union. Without the right to associate freely, the union will lose its relevance as no one individual can single-handedly face the force of the employer. More so should the employer fail to honour a collective agreement entered between them, the union can enforce the implementation of the agreement through strike or other lawful way of putting pressure on the employer to honour the agreed terms.

Some conventions and treaties also subscribe to the right of members to freely associate and join unions. Article 8 (1) (a) of the International Covenant on Economic, Social and Cultural Rights, mandates States which have ratified the covenant to protect the right of every individual to form or join a trade union: It states: 
The right of everyone to form trade union and join trade union of his choice, subject only to the rule of the organization concerned, for the promotion of his economic and social interest. No restriction may be place on the exercise of his right other than those prescribed by law and which are necessary in a democratic society in the interest of national security or public order or for the protection of the right and freedoms of others (ICESCR, 1966).

Equally, Article 11 of the African Charter on Human and Peoples Right (Ratification and Enforcement) Act provides that:

Every individual shall have the right to assemble freely with others. The exercise of this right shall be subject only to necessary restriction provided for by law in particular those enacted in the interest of national security, the safety, health... and rights and freedom of others (ACHPR, 1981).

Until the late nineteenth century, strikes were generally considered to be unlawful activity of a criminal nature and they were unlawful in many countries of the world till the mid-twentieth century. It is important to note that up till now in Nigeria, strike still has a criminal colouration where the laid down procedure is not followed.

The right to strike has now become a fundamental right recognized by a large majority of countries around the world as embodied in the United Nations International Covenant on Economic, Social and Cultural Rights 1966 and has been protected by the International Labour Organization (ILO) supervisory bodies (principally the Committee on Freedom of Association since 1952 and the Committee of Experts on the Application of Conventions and Recommendations since 1959. The decisions of these supervisory bodies have given rise to a body of principles on the right to strike broadly shared by the international community and based on general principles of freedom of association embodied in the ILO constitution and in the core Convention on this subject (Khan-Freund \& Hepple, 1972). From the foregoing, it is apparent that the International Labour Organization and the African Charter on Human and Peoples Rights are supportive of the employees and employers to form or organize unions. Article 2 of the International Labour Organization Convention 87 on Freedom of Association and Protection of the Right to Organize 1948 provide as follows:

Workers and employers, without distinction whatsoever, shall have the right to establish and subject only to the rules of the organization concerned, to join organizations of their own choosing without previous authorization (ILO, 1960a).

The respect for freedom of association around the world is a fundamental and unavoidable requirement for the International Labour Organization because it is one of the most essential characteristic, namely tripartism, and the important responsibilities based on the Constitution and ILO instruments that employers' and workers' organizations are called upon to exercise within the organization 
itself as well as within the different member states.

The International Labour Organization Declaration on Fundamental Principles and Rights at work adopted by the ILO Conference in 1998 makes compulsory for all member states to respect the fundamental rights which include the right to freedom of association. The Convention declares that all Members, even if they have not ratified the Conventions in question, have an obligation arising from the very fact of membership in the organization, to respect, to promote and to realize, in good faith and in accordance with the Constitution, the principles concerning the fundamental rights which include freedom of association (ILO, 1998). Without freedom of association employers' and employees' organization that are independent and autonomous representative and empowered with the necessary rights to defend the rights of their members and advancement of their common welfare, the principle of tripartism would be greatly impaired if not completely eroded of all meanings and chances for greater social justice would altogether be seriously be jeopardised.

As freedom of association is one of the principles safeguarding peace and social justice, it is entirely understandable, on the one hand, that the ILO has adopted a series of conventions, Recommendations and Resolutions which form the most important international source on this subject, and, on the other hand, that in addition the general supervisory machinery, in particular the Committee of Experts on the Application of Conventions and Recommendations, a special procedure has been created for the effective protection of trade union rights; this special procedure was entrusted to the Fact-Finding and Conciliation Commission on Freedom of Association and the Committee on Freedom of Association. The principles of the Committee on Freedom of Association and the Committee of Experts concerning the right to strike have been set forth in the general principles of freedom of Association. This right has been affirmed in the International Labour Organisation Resolution of 1957 concerning the Abolition of Anti-Trade Union Legislation in the Members States of the International Labour Organization and the ILO 1970 Resolution concerning Trade Union Rights and their Relation to Civil Liberties (ILO, 1970), as well as other ILO's regional conferences and industrial committees, and by other international bodies.

The International Labour Organization has highlighted the principles and minimum rules of conduct established by the Committee of Experts and by the Committee on Freedom of Association as the right to strike which is stated thus:

Consideration of the right to strike as a fundamental right to be enjoyed by workers and their organizations (trade unions, federations and confederations), which is protected at international level, provided that the right is exercised in a peaceful manner. (Gernigon et al., 1998)

The committee has also outlined certain conditions for the support of the right of workers to embark on strike:

1) General acceptance of the right to strike for public and private employees, with the exception of members of the armed forces and police, public servants 
exercising power on behalf of the State and workers employed in essential services in the strict sense of the term (the interruption of which could endanger the life, safety or health of all or part of the population life, safety or health of all or part of the population, or in acute national crisis situations.

2) The principles of freedom of association do not include acts of a purely political nature, but they include those seeking a solution to major economic and social policy issues.

3) A blanket ban on solidarity strikes would result in violence. Workers will enjoy the right to take such action when the initial strike they are endorsing is lawful in itself.

4) In all cases of strike action, a minimum security service may be implemented where such minimum services are intended to ensure persons ' health, accident prevention, and machinery and equipment protection.

5) A minimum operational service may be established (in the undertaking or institution in question) in the case of strike in public utility services and in public services of fundamental importance; employers' and worker' organizations and the public authorities should be able to participate in determining this minimum service.

6) The requirement to offer prior notice, the obligation to participate in conciliation, access to binding arbitration, comply with a given quorum and obtain the approval of a given majority in situations where this does not make the strike very difficult or even impossible in practice and the secret ballot method to decide strike action are all acceptable conditions for the exercise of the right to strike.

7) Restriction on picketing should be limited to cases in which such activity fails to be non-violent, and picketing should not interfere with the freedom to work of non-strikers.

8) Requisitioning of the workers of an undertaking or institution in the event of a strike is admissible only in the case of a strike in an essential service or under circumstances of utmost gravity and in situations of acute national crisis.

9) In acute national crisis cases, employment of workers to replace strikers severely impairs the right to strike and is only appropriate in strikes in an essential service or in an acute national crisis.

10) Legal provisions regarding wage deductions for days of strike give rise to no opposition.

11) Appropriate protection should be afforded to trade union officials and workers against dismissal and other detrimental acts at work for organizing or participating in a legitimate strike, in particular through prompt, efficient and impartial procedures, accompanied by sufficiently dissuasive remedies and sanctions.

12) The protection of freedom of association does not cover abuses in the exercise of the right to strike involving failure to comply with reasonable requirements regarding lawfulness, or consisting of act of criminal nature; any sanctions imposed in the case of abuse should not be disproportionate to the se- 
riousness of the violations.

The importance of ILO principles on the right to strike as enunciated by the supervisory bodies becomes evident when one realizes the extent to which substantial restrictions on fundamental trade union rights undermines not only the balance of labour and relations and the existence of a counter balance to the power of the State in the economy, but also reduce expectations of any improvement in conditions of employment and in the standard of living within civil society in the present globalized economy.

One is therefore, bound to acknowledge the contribution of the ILO Committee on Freedom of Association and the Committee of Experts to the development of present international law most especially with regard to the right of the workers to strike.

\section{The Right to Strike in Nigeria}

Nigeria being a Colony of Britain operated the common law rule. To have a fair historical perspective on the right to strike in Nigeria, it is pertinent to consider the common law position with regard to the right to strike. At common law, the contract of employment requires the employee to offer service to his master faithfully and without any iota of disobedience. There is no doubt therefore at common law that an employee who goes on strike would have fundamentally breached his contract of employment. This principle of law was firmly established in Rookes $v$ Barnard (1963) by Donovan L. J. when he said that "there can be few strikes which do not involve a breach of contract by the strikers". At common law, an employee will therefore be in breach of his contract of employment if he refuses to work or carry out the legitimate instruction or order of his master (Canadian Pacific Railway Company v. Zambin, 1968).

In Nigeria, the law on strike has experienced a chequered legal regime. The promulgation of Trade Disputes (Emergency Provisions) (Amendment No. 2) Decree No. 53 of 1969 is believed to be one of the severe trade disputes law in Nigeria. The decree completely banned the use of strike as a means of settling trade disputes. The decree further provided for a jail term of 5 years for striking workers. This decree was unpalatable for Trade Union development as the right to strike was out rightly banned.

However, in 1976, the then Military government promulgated yet another decree which tacitly guaranteed the right to strike. This decree repealed the 1969 Trade Disputes (Emergency Provision) decree and has now metamorphosed to Section 18 of the Trade Disputes Act (TDA, 2004).

The point needs to be made that in Nigeria, there exists a contentious argument by two schools of thought on the issue of the right of the Nigerian worker to strike following the introduction of the statutory provisions of Section 17 (1) of the Trade Disputes Act of 1976 (now Section 18 (1) and (2)) of the Trade Disputes Act.

It is contended by one school of thought that the introduction of Section 17 (1) and subsequent amendment of the section has utterly taken away the right of 
the Nigerian worker to embark on a lawful strike. Other statutes that equally impinge on the right of the Nigerian worker to strike are Sections 31 (6) (e) of the Trade Unions Act (TUA 2005), 43 (1) Trade Disputes Act (TDA) and Section 1 Trade Disputes (Essential Services) Act (1976). This Act empowers the President and Commander-in-Chief to proscribe any trade union or association and the omnibus provisions of Section 45 of the 1999 Nigerian Constitution. It is the contention of this school that with the introduction of Section 17 (1) of the Trade Disputes Act, 1976 (now Section 18 (1)) a new vista of trade dispute resolution mechanism has been opened and the question is whether the Nigerian worker still has a right to embark on a lawful strike in the light of these provisions. Many learned authors have submitted that with this new statute in force, the Nigerian worker has totally lost his right to strike.

Uvieghara, one of the leading contenders of this school of thought argues that the introduction of Section 17 (1) now Section 18 (1) of the Trade Disputes Act, 2004 , as amended prohibits the right of Nigerian workers to embark on a lawful strike. According to him, "the purpose of setting out Section 17 (1) now Section 18 (1) in full is to show that it does not leave any room for a lawful strike". Its effect, he submitted, is to prohibit strike completely (Uvieghara, 2001).

Emiola has also acceded to this line of thought contending that Section 17 (1) now Section 18 (1) has removed the right of the Nigerian worker to go on a lawful strike. He states:

But there is nothing to suggest from the close reading of subsection 1, of Section 17 (1) (now Section 18 (1)) that a strike can legally take place while one of the six processes is in progress, and Section 14 (2) now S. 13 (2) can have no other imputation than that no strike can also take place after the award under subsection 1 (f) of that section. The true construction of the new provisions, therefore, is that none of the parties to an industrial dispute can take industrial action while negotiations and other steps enumerated under Section 18 (1) of the present Act are in progress. It will be a criminal offence to do so (Emiola, 2008).

Aligning with the position taken by Emiola and Uvieghara, Iduborhas also submitted that as long as Section 18 (1) is in force, any strike embarked on by workers is in the breach of the extant Act and therefore illegal. According to him, "on the true construction of this section, none of the parties to a trade dispute can take industrial action if the prohibition remains during the intervention of a mediator, if at the conciliation level the prohibition remains in force." (Idubor, 1999). Also towing this line of thought, Abuza has submitted that there is no loophole in the strike law which workers can exploit to embark on a legal strike. Section 18 (1) TDA prohibits any strike in connection with any trade dispute where the procedure specified. In Section 4 or 6 of the TDA has not been complied with in relation to the dispute (Abuza, 2016).

Recently, Erugo corroborated the views of Emiola and Uviegahara when he said the process required by Section 18 (1) which makes reference to Sections 4, 
$6,8,9,13$ (3) and 14 (1) confirms that the disputing parties lose the right or freedom to bargain. The back and forth process of the negotiation in an attempt to satisfy the pre-conditions to embark on strike under the present law would be an exercise in futility. In fact, being a statutory inhibition, the sections appear to have buried whatever recognition of the right to strike. More so, subsection (2) is a manifest repression of the right to strike having criminalized the circumvention of subsection (1) of the Act (Erugo, 2019).

In the same vein, Okene has submitted that the wording of the section seems not to leave any room for a lawful strike. He contends that the effect of the section is to prohibit strikes completely. According to Okene, by virtue of the section, workers cannot go on strike unless they observe the dispute settlement procedures. But, if at the end of the process, workers are dissatisfied with the award of the National Industrial Court, whose decision is final, then by virtue of Section 18 (3) they must go through the whole process of dispute settlement all over again. Thus, the law has apparently created a vicious circle of compulsory arbitration from which the workers cannot escape. By implication, the right to strike seems to have been smartly circumvented by the legislature (Okene, 2007).

Finally, Worugji and Archibong have also towed the line of the school that the combined effect of Section 18 (1) (2) (3) of the Trade Disputes Act, and the provisions of Section 1 Trade Disputes (Essential Services Act) 1976, totally inhibits the right of the Nigerian worker to embark on a lawful strike (Worugji \& Archibong, 2009).

The other school of thought on the contrary, completely disagrees with these submissions. They hold the strong view that in spite of the introduction and amendment of Section 17 now Section 18 (1) of the Trade Disputes Act, the right of the Nigerian worker to strike has not been removed. They rely on statutory provisions and case law in asserting this view. By virtue of Section 40 of the 1999 Constitution, the right to peaceful assembly and association and in particular to form or belong to any trade union is protected. The section provides:

Every person shall be entitled to assemble freely and associate with other persons, and in particular he may form or belong to any political party, trade union or any other association for the protection of his interests.

It is emphasized by those of this liberalist school of thought that the constitutional provision guaranteeing the freedom of association, including the formation and joining of a trade union has the legal effect of legitimatizing strike as the basis of the union negotiating and collectively bargaining on behalf of its members. Supporting the connection between collective bargaining and the right to strike, Adeogun notes that:

The freedom to strike and lock-out is a concomitant of the collective bargaining process in that the system succeeds only to the extent that the two parties "collective" parties are unmistakably aware of the strength of either party to organize successful industrial action to make the other negotiate or to compel observance of the agreement reached. (Adeogun, 1972) 
Khan-Freund is also of the view that the ability of the trade union to embark on a lawful strike is the only way that their strength can match the supreme power of the employer to discipline and dismiss its employees. He went further to state that "in the context of the use of strike as a sanction in industrial relations, the equilibrium argument is the most important... the concentrated capital can only be matched by the concentrated power of the workers acting in solidarity" (Khan-Freund \& Hepple, 1972). Bellace has also submitted that without the right to strike, without the ability to threaten economic loss to the employer, unions lack bargaining power. Without the ability to press demands and to back up those demands with the threat of using economic weapons, workers effectively cease to be able to bargain (Bellace, 2016). Any book on negotiation will devote significant space to the basic concept of leverage (Shell, 2006). The French Constitution of 1946 and 1958 respectively lay down that the right to strike should be exercisable within the framework of the laws regulating it. The decision of the Irish Supreme Court in Educational Cov. Fitzpatrick (No. 2) (1961) is very appropriate in this regard; the court held that the right to strike could be implied from the Constitutional right of freedom of association. In the same vein, the dissenting judgment of Smith, CJM of the Manitoba Court of Appeal implies that the law is trite.

There can be no doubt that the right to strike has long been recognized as a fundamental right of labour, and though questions are being asked about how greatly the exercise of that right should be permitted to injure the general public, and whether in some industries, or in some circumstances strikes should be prohibited, the principle of the right to strike still stands (Contractors Equipment \& Supply (1965) Ltd. 1965).

Both Akpan and Nwabueze have submitted that Section 18 (1) of TDA is void for being inconsistent with Section 34 (1) (c) of the 1999 Constitution of the Federal Republic of Nigeria (as amended), which prohibits forced labour. They opined that the prescriptive implication of the statute is to force labour to bow at all times to the whims and caprices of the employer thereby forcing an unwilling servant on a willing master. They concluded that since the Constitution is the supreme law of the land, it supersedes the Trade Disputes Act and therefore the contemplated right to form and join a trade union guarantees the right to strike. They summarized by saying that the right to collective bargaining cannot be separated from the right to press forward the demands of the union should the negotiation fail or breakdown (Akpan, 1996; Nwabueze, 1993). Oshio, has postulated that the right to strike survives in Nigeria by virtue of common law. According to him, at common law an employee has a right to go on strike as long as they have given adequate notice to the employer of his or their intention to go on strike (Oshio, 1996). The right to strike is judicially recognised at common law. In Crofter Hand Woven Tweed Co. Ltd. v. Veitch (1942) Lord Wright had this to say:

When the rights of labour are concerned, the rights of the employer are 
conditioned by the rights of the men to give or withhold their services. The right of the workman to strike is an essential element in the principle of collective bargaining.

Supporting this line of argument, Ukhuegbe submits that the compulsory process of Section 17 (1) now Section 18 (1) of the Trade Disputes Act violates Nigeria's obligation under Article 4 of the International Labour Organization (ILO) Convention No. 98 which enjoins state parties to promote:

Voluntary negotiation between employer and employer organization and workers' organizations, with a view to regulating the terms and conditions of employment by means of collective agreements. (Ukhuegbe, 1996)

The word "voluntariness" means or implies that labour should be able to use all the weapons in its armoury or at its disposal to contend with its opponent. $\mathrm{He}$ further emphasized that the right to strike can be inferred from Article 10 of the African Charter on Human and Peoples Rights which provides that "Every individual shall have a right to free association provided that he abides by the law". Furthermore, he said when Article 10, is read side by side with the right to personal dignity (Article 5) and the right to work under equitable and satisfactory conditions (Article 15) there exist an unimpeded right to strike. The veracity of this argument alludes to the fact that once an international treaty has been ratified and domesticated it enjoys full implementation in that country. In Abacha v. Fawehinmi (2000), the apex court held that since the African Charter has been domesticated or has been incorporated into Nigerian municipal Lawby its ratification, it enjoys the status higher than a mere international Convention. It becomes part of Nigeria's domestic or municipal law. It is further submitted that a violation of these Conventions ratified by Nigeria may attract sanction from these international organizations.

Accordingly, Orifowomo argues that there is a loophole in the dispute resolution mechanism that can be exploited by workers to embark on lawful strike. The loophole, according to him, is that whereas the public policy makes strike illegal after a dispute has been reported and is being subject to dispute settlement processes, strikes can still legally and logically occur before the disputes are reported and settlement commenced (Orifowomo, 2004).

The International Labour Organization (ILO) has consistently considered freedom of association and the right of collective bargaining to be amongst the core rights that are at the very threshold of ILO's mission. Besides these Conventions and recommendations, the significance of the right to strike in relation with the right to collective bargaining has been overtly acknowledged by the ILO Committee on Freedom of Association. In 1960 the Committee declared that:

The right to bargain freely with employees with respect to conditions of work constitutes an essential element in freedom of association, and trade unions should have the right, through collective bargaining or other lawful means; to seek to improve the living and working conditions of those the 
trade unions represent and public authority should refrain from any interference which would restrict this right or impede the lawful exercise thereof (ILO, 1960b).

In June 1998, the ILO adopted the declaration on Fundamental Principles and rights at work. The declaration encompassed the principles of eight fundamental Conventions (the Eight Fundamental Conventions) and accordingly enjoined all member States to observe these principles regardless of ratification, as a condition precedent for membership. As stated in the declaration:

All members even if they have not ratified the [fundamental] Conventions have an obligation, arising from the very fact of membership in the organization, to respect, promote and or realize, in good faith and in accordance with the constitution, the principles concerning the fundamental rights which are the subject of those [fundamental] conventions. (ILO, 1999)

The ILO Committee of Experts on Freedom of Association at its meeting in 1996 resolved that respect for principles of Freedom of Association requires that employees should not be dismissed or refused re-employment on account of their having participated in a strike. The committee stated that the right to strike is a right which employees are entitled to enjoy so long as the objective of the strike is to promote and defend the economic and social interests of employees. Political and lighting strike (a form of protest in which workers stop doing their job without giving their employer any warning or notice) are excluded; sympathy strike is supportable provided the initial strike being supported is itself lawful (Gernigon et al., 1998).

The argument on whether the Nigerian worker in the face of Section 18 (1) of the Trade Disputes Act, can embark on a lawful strike is very interesting. The assertion of the proponents of strike prohibition appears true on the face of the literary meaning of the statutes. Subsection (1) of the section clearly outlined the condition precedent before a lawful strike could be carried out in Nigeria. Their argument is further sustained by subsection (2) which criminalises the act of any party who circumvents the subsection of the Act. Candidly, both Emiola and Uvieghara admit that once a party has fulfilled one of the conditions specified in the subsection, the party can legitimately embark on a strike. They relied on the decision in Eche V. State Education Commission (1993) where the court held that it is only when one of the conditions enumerated in the subsection has been complied with that a strike action can be said to lawful.

There are various laws in Nigeria and Conventions which dwell on the right to strike, some are prescriptive and others are permissive. This diversity of laws has made the legal regime on the right to strike very fluid and unsettled in Nigeria. This state of confusion is very evident when one takes a closer look at the Nigerian Constitution, statutes and International Conventions that Nigeria has ratified. These laws read together or interpreted separately shows that there is no clear cut position as to the right to hold a lawful strike in Nigeria. Some statutes 
tend to be supportive of the right to strike and at the other end there exists conditions to be observed before the right can be exercisable. To buttress this view, we shall take a quick and critical look at some of these laws.

\section{The Constitution}

Chapter four of the 1999 Constitution of the Federal Republic of Nigeria under the Fundamental Human Rights, provide some privileges which accrue to the citizenry, particularly section Sections 39, 40 and 41 (1) of the 1999 Constitution of Nigeria. These sections entrench the right to freedom of expression and movement. All these sections further strengthen the right of the individual or group of individuals who are guaranteed these liberties, freedom to associate and freedom to express their feelings, views and opinions within the ambit of the law. On the contrary, these fundamental rights to freedom are not exercisable without some form of limitation. Section 45 (1) of the Constitution states that:

Nothing in Sections 37, 38, 39, 40 and 41 of this Constitution shall invalidate any law that is reasonably justifiable in a democratic society-

1) In the interest of defence, public safety, public order public morality or public health; or

2) For the purpose of protecting the rights and freedom of other persons.

This section no doubt limits the extent to which these fundamental freedoms could be enjoyed. Without doubt, the economic effect of strike on individuals and society is so disastrous especially where the strike is prolonged and will affect the entire country hence under Sections 41 and 42 of the Trade Disputes Act of 2004, it cannot probably be allowed to be exercised unchecked.

It is clear from Sections 39, 40 and 41 of the Constitution, especially Section 40 that citizens of Nigeria can as of right form a trade union or join one without any form of restriction and be free to express their opinion without fear or favour. More so, one of the ingredients of trade unionism is the right or freedom of the union to express itself and protect the interest of the union and its members through negotiation, collective bargaining and in the worst case scenario to embark on strike to press home their demands.

\section{Other Nigerian Statutes}

Section 18 (1) and (2) of the Trade Disputes Act (2004) dwells on the issue of strike with clear prescription of conditions to be fulfilled before any person or trade union can embark on a lawful strike. Apart from fulfilling these conditions, any person who violates this section is punishable upon conviction to a fine of \#100 and imprisonment for a term of six months for individual and a fine of \#1000 for body corporate. This section is really a clog on the right of the Nigerian worker to go on strike, especially with the imposition of imprisonment terms against those who circumvent subsection (1).

Section 31 (6) (e) of the Trade Unions Act also prescribes conditions for trade union to meet especially subsection 6 (e) before calling its members to go strike. 
The section provides as follows:

No person, trade union or employer shall take part in a strike or lock-out or engage in any conduct in contemplation or furtherance of a strike or lock-out unless:

1) The person, trade union or employer is not engaged in the provision of essential services;

2) The strike or lock-out concerns a labour dispute that constitutes a dispute of right;

3) The strike or lock-out concerns a dispute arising from a collective and fundamental breach of contract of employment or collective agreement on the part of the employee, trade union or employer;

4) The provisions for arbitration in Trade Disputes Act, Cap. T8, Laws of the Federation of Nigeria, 2004 have first been copied (sic) with; and

5) In the case of employee or trade union, a ballot has been conducted in accordance with the rules and constitution of the trade union at which a simple majority of all registered members voted to go on strike.

This subsection sets out preconditions for strike, with paragraph (5) being the most onerous. It requires a simple majority vote of all registered members to vote in support of strike before a valid and lawful strike can be embarked upon. The question that arises therefore is, what is a "simple majority"? According to the Black's Law Dictionary, simple majority vote is the voting requirement for more than half of all ballots cast (Garner, 2004). It therefore follows that for there to be a valid vote cast in support of strike more than half of all its registered members must vote in support of the strike as against a quorum that will be determined by the rules and constitution of the union. This sub-paragraph is also prohibitive of a lawful strike action, as we can see it is almost practically impossible for a majority of all registered members of the labour unions who are in millions to actually gather in a particular venue to cast a vote affirming the union to go on strike. Even where they are to attend the meetings at their different location or branches, and thereafter collate votes cast by the national body, the idea of a simple majority vote of all its registered members attending and voting in favour of strike is still onerous. Again to convince its members to attend the meeting and obtain simple majority votes as against a quorum in every branch is a difficult task due to the large number of people. The requirement of a simple majority vote of all its registered members to participate in the voting is a herculean task and therefore a clear manifestation of the intention of the statute to prohibit strike. There is little or no doubt from the conditions outlined that a trade union cannot go on strike, except these conditions are met.

Paragraph (1) prohibits those in the provision of essential services from going on strike. This perceived intention is clearer from the provision of Section 41 (1) of the Trade Disputes Act; which requires at least fifteen days notice for those workers in Essential Services before embarking on a strike action. The subsection reads: 
Without prejudice to Section 18 of this Act, if any worker employed in any essential services ceases, whether alone or in combination with others, to perform the work which he is employed to perform without giving his employer at least Fifteen days' notice of his intention to do so, he shall, unless he proves that at the time when he ceases to perform that work he did not know, or had no cause to believe, that the probable consequences of his or their doing so would be to deprive the community or any part of the community either wholly or to a substantial extent of that or any essential services, be guilty of an offence and be liable on conviction to a fine of \#100 or to imprisonment for a term of six months.

Here again, there is a strict restriction on employees performing essential services from embarking on strike as long as the condition of fifteen days notice is not observed. Furthermore, the section criminalizes the non-observance of the condition. The question that readily comes to mind is would this notice apply to a condition were the life or lives of the worker or workers is in danger or extreme danger? This may not necessarily apply especially where the health of the worker or workers is at great risk.

Though. these statutes prescribe methods to be judiciously followed in resolving disputes before trade unions can embark on strike, particularly Sections 18 (1) Trade Disputes Act, Sections 31 (6) (e) Trade Unions Act and 41 Trade Disputes Act, the provisions of Section 43 (1) of the Trade Unions Act appear to legitimatize strike indirectly. This section allows for peaceful picketing. The section provides:

It shall be lawful for one or more persons, acting on their behalf or on behalf of a trade union or registered federation of Trade Unions or an individual employer or firm in contemplation or furtherance of a trade dispute, to attend at or near a house or place where a person resides or works or carries on business or happens to be, if they so attend merely for the purpose of peacefully obtaining or communicating information or of peacefully persuading any person to work or abstain from working.

It is presumed that with the existence of this provision in force the persuasion of person or persons to dissuade them from going to work or working at all is legitimate as long as it is in contemplation or in furtherance of a trade dispute.

\section{The Right to Strike in Other Jurisdictions}

These will be examined under three jurisdictions namely: South Africa, United Kingdom and Ghana.

\subsection{South Africa}

In South Africa, the major laws governing labour relations are the Labour Relation Act (1995) and the Bill of Rights (1993). The right to strike is well provided for in the South Africa Bill of Rights whereas the Labour Relations Act regulates 
strike action. These laws are aimed at creating economic development, social justice, labour peace and the freedom and democracy of workers.

South Africa is one of the few countries in Africa where workers are allowed by statute to embark on strike when in dispute with their employer. It is perhaps the only country in Africa that has elected to entrench the right to strike as a fundamental constitutional right. South Africa has fully given effect to its obligation to domesticate the International Labour Organisation (ILO) Conventions by ratifying Convention 87 of 1948 and convention 98 of 1949 and entrenching same in the Constitution (Constitution of the Republic of South Africa, 1996). Section 23 (2) (c), provides that "every worker has a right to Strike". Again, Section 64 (1) of the Labour Relations Act (LRA) provides that every employee has a right to strike and every employer has the right to lock-out. However, this right can only be limited by Section 36 of the 1996 Constitution which provides as follows:

The rights in the Bill of Rights may be limited only in terms of law of general application to the extent that the limitation is reasonable and justifiable in an open and democratic society based on human dignity, equality and freedom, taking into account all relevant factors, including:

a) The nature of the right;

b) The importance of the purpose of the limitation;

c) The nature and extent of the limitation;

d) The relation between the limitation and its purpose; and

e) Less restrictive means to achieve the purpose.

(2) Except as provided in subsection (1) or in any other provision of the Constitution, no law may limit any right entrenched in the Bill of Rights.

Section 77 of the Labour Relations Act of South Africa, also allows trade union to protest against policies which are inimical to the socio-economic interest of workers. It follows therefore that when government makes policies which adversely affect the economic well-being of the worker, the Union can go on a public protest against such policies (political activism). Most interesting also, is the fact that trade union members can take part in political activism. They can participate in protest action against government policies which are inimical to the socio-economic wellbeing of the general public provided such employee is not engaged in the provision of essential services under Section 77 (1) of the Labour Relations Act of South Africa. Unlike Nigeria where the right to strike is prohibited and punishable by fine and imprisonment, the right to strike is constitutionally protected and guaranteed under the South African Constitution. This makes protected or lawful strike very functional. Both the employees and employers know that in the event that their collective bargaining fails, either of the parties has an unhindered right to strike and therefore parties take their negotiation and agreements seriously.

The judiciary has also taken notice of this when in the case of Bawa \& Ors V. Prestige Hotels (1993). The court held that by definition, a lawful strike is functional to collective bargaining. The parties are forced to take negotiation se- 
riously by the fear that if settlement is not reached either of the parties might exercise their right to inflict economic harm on the other. In Nigeria, the rigorous processes to be followed before a strike will be lawful or protected make it near impossible to have a lawful strike. More so, the conditions specified in Section 18 (1) of the Trade Disputes Act and failure to comply would incur the weighty hand of the law by paying fine or imprisonment or both as provided for in Section 18 (2) of the Act is a clear manifestation of the restriction on the right to strike.

Whereas in South Africa, trade unions can go on public protest when government makes policies that have negative effect on the socio-economic wellbeing of the workers, in Nigeria, trade union cannot go on strike or join public protest where the issue is not in contemplation or furtherance of trade disputes. Even when such issues are of right, those in essential service are not likely to be allowed to join the strike as Section 41 of the Trade Disputes Act prohibits such worker from embarking on strike without first giving fifteen days notice to their employer before embarking on such strike.

\subsection{The United Kingdom (UK)}

The United Kingdom does not have a written constitution and there is no clear or inherent right to participate in strike action. Nevertheless, the law has provided for some form of immunities for tortuous liabilities committed in the course of embarking on strike action at common law. Though, these immunities exist, they are still subject to some form of restrictions and other mandatory rules contained in Trade Unions and Labour Relations (Consolidation) Act 1992 (TULRCA). For these immunities to avail one, the strike must be "in contemplation or in furtherance of trade dispute" other than this, even where such trade dispute exists, the union will still lose its statutory immunities unless the strike or industrial action has been properly motivated in accordance with set out procedures in the Trade Unions Labour Relations (Consolidated) Act and the Code of Practice on Industrial Action and Ballot and Notice to Employers 2000. It is important to state that in spite of these conditions, TULRCA does not provide any positive right to strike in the United Kingdom.

Honeyball and Bowers assert that "it is virtually impossible in modern Britain to take industrial action which is lawful...” The consequences of this are naturally serious. A participant in industrial action may be dismissed, suspended, lose of pay and may lack qualification for job seeker's allowance and other fringe benefits (Honeyball \& Bowers, 2014).

Most labour law scholars in the United Kingdom agree that there is no positive right to strike and that a change is most desirable (Hepple \& Freeman, 1992). According to Sheldon, those who believe that the changes in legislation or developments in common law unduly restrict their ability to strike can only fall back on the various international treaties and conventions to which the United Kingdom is a party (Sheldon, 1992). Contrary to the view expressed by Sheldon, not all such treaties and conventions protect the right to strike, for example, the 
European Convention on Human Rights (ECHR). The argument that freedom of association as guaranteed by Article 11 of the ECHR must include the right to strike was rejected in the case of Schmidt and Dahlstorm v. Sweden (1980). In this case, the applicants were members of a striking union and they were consequently denied of certain fringe benefits on account of participating in the strike. They argued that by denying them these benefit violated their right to freedom of association as provided for in Article 11. But the European Court of Human Rights held that while Article 11, specifically mentions the right to join trade union as a species of the more general right of association, this does not imply that it necessarily includes the right to strike.

However, they may rely on other treaties and conventions such as the International Covenant on Economic, Social and Cultural Rights (ICESCR) which expressly recognises the right to strike.

\subsection{The Republic of Ghana}

The right to strike is well enshrined under the Labour Act of Ghana 2003. Disputing parties are however first encouraged to negotiate and settle the dispute by their own agreed methods. The Ghanaian National Labour Commission may also intervene in disputes and seek settlement by mediation and where this fails by arbitration (Labour Act of Ghana, 2003). Where parties are unable to settle after arbitration, either of the disputing parties may give seven days notice of its intention to embark on strike in the case of employees or lock-out by the employers (LA. Section 159). Most importantly, Section 160 of the Act overtly provides for the right to strike. It states that a worker can go on strike subject to the giving of seven days notice which must expire before the strike action is embarked upon. Like in other jurisdictions, the right to strike is also prohibited in essential services which are defined in line with International Labour Organisation (ILO). The Act also protects striking employees from dismissal and hiring to replace labour in course of strike.

\section{Recommendations}

In Nigeria, there exist several legislations which purport to prohibit and criminalize strike action and prescribe punishment for those who participate in strike action without following due process. An example is Section 18 (1) and (2) of the Trade Disputes Act and Section 31 (6) (e) of the Trade Unions Act and Section 1 Trade Disputes (Essential Services) Act. In the light of Nigeria being a party to the ILO Convention, as well as the International Covenant on Economic Social and Cultural Rights, the criminalization of strike action by our domestic legislation is in sharp conflict with the spirit and letters of these instruments. The said sections in the provisions should therefore be expunged as soon as possible by the National Assembly.

Furthermore, the stringent procedure to be followed before a strike could be deemed lawful or protected makes it near impossible to have a lawful strike. Failure to comply with the conditions specified in Section 18 (1) of the Trade 
Disputes Act is deemed to be a crime and may result in the payment of fine or a term of imprisonment or both. The provisions of Section 31 (6) (e) of the Trade Disputes Act which require a simple majority vote of all registered members of a trade union is also a clog in the wheel of industrial harmony and more particularly, the right to strike. Even more draconian is the power given to the President to proscribe any trade union or association of employee engaged in essential services, taking cognisance of the elaborate meaning of "essential services" in the Act. These sections should without more, be expunged from the enactment.

Unlike Nigeria, trade unions in South Africa and Ghana can go on strike as of right as this is provided for in their Constitution and Labour Act. This is allowed where the government or employers fail to honour agreements or make policies that have negative impact on the socio-economic well-being of the workers and the society in general. It is suggested that the position in South Africa and Ghana where the right to strike is expressly enshrined and guaranteed in the Constitution and Labour Act, should be followed by Nigeria.

\section{Conclusion}

On the whole, the contention of Emiola, Uvieghara and other proponents that with the introduction of Section 18 of the Trade Disputes Act, Nigerian workers have totally lost their right to strike based on the far reaching effect of the provision is indeed unfounded. It is clear, having critically looked at relevant laws and submissions of various writers and judicial pronouncements on the foregoing issue, it can be safely asserted that though there appear to be some obvious limitations or restrictions to the exercise of the right to strike in Nigeria; however, these laws have not in any way totally banned or removed the use of strike as a means by which trade unions could press home their demands where negotiations fail. The laws, especially Section 18 (1) TDA and Section 31 (6) (e) TUA are essentially formulated in our view to curtail the rampant, unwarranted and indiscriminate use of strike as a means of coercion in Nigeria.

The cumulative effects of Sections 18 (1) TDA, 31 (6) (a) \& (b) and (7) and section 12 (4) TUA, do not have the potency of banning the right of the Nigerian workers to strike. This is as a result of the provisions of Article 11 of the African Charter on Human and Peoples Rights (Ratification and Enforcement) Act, as well as Article 89 of the ILO Convention which provides for freedom of association and freedom of the Union to bargain collectively. Nigeria as a member of these organizations and having ratified these Conventions cannot ban strike. Even where they have not ratified these conventions, the mere fact of their membership obligates them to honour the right to strike flowing from the freedom of association. The constitutional provision of Section 40 of the 1999 Constitution of the Federal Republic of Nigeria which is in parimateria with Article 11 of the African Charter on Human and Peoples Rights (Ratification and Enforcement) Act, together with Article 8 (1) (a) of the International Covenant on Economic, Social and Cultural Rights guarantees the use of strike by the mere fact that people are free to join associations and trade unions of their choice for 
the defence of their interest and the interest of their organization, making the right to strike a fundamental right, insofar as it is not inconsistent with the provisions of Section 45 of the 1999 Constitution of Nigeria.

Again, Section 43 of the Trade Disputes Act, also guarantees trade unions the right to picket and creates immunity against any offence while carrying out this process in a peaceful manner. In all, the right of the Nigerian worker to go on lawful strike has not been removed. At best, one would say that the right has been curtailed but certainly not extinguished.

\section{Conflicts of Interest}

The authors declare no conflicts of interest regarding the publication of this paper.

\section{References}

Abacha v. Fawehinmi (2000). 6 Nigerian Weekly Law Reports 660, 228 (SupremeCourt).

Abuza, A. E. (2016). A Reflection on Regulation of Strikes in Nigeria. Commonwealth Law Bulletin, 42, 3-37. https://doi.org/10.1080/03050718.2015.1115731

Adeogun, A. A. (1972). Industrial Relations and the Law. In T. O. Elias (Ed.), Law and Development (p. 122). Lagos: University of Lagos Press.

African Charter on Human and Peoples Rights (ACHPR) (1981). (Ratification and Enforcement) Act, Cap. 10 Laws of the Federation of Nigeria 1990.

Akpan, G. (1996). The Right of Workers to Strike in Nigeria. Lawyers Bi Annuals, 3, 62-74.

Bawa \& Ors v. Prestige Hotels (1993). 14 ILJ, 963, (LCA).

Bellace, J. R. (2016). Back to the Future: Freedom of Association, the Right to Strike and National Law. King's Law Journal, 27, 24-45. https://doi.org/10.1080/09615768.2016.1144430

Canadian Pacific Railway Company v. Zambin (1968). SCR 609.

Chianu, E. (2004). Employment Law. Bemicov.

Constitution of the Federal Republic of Nigeria (as Amended) (1999).

Constitution of the Republic of South Africa 1996.

Crofter Hand Woven Tweed Co. Ltd. v. Veitch (1942). A.C. 435, 463.

Eche v. State Education Commission (1993). 1 Federation of Nigeria Law Report 386.

Educational Co. v. Fitzpatrick (No. 2) (1961). IR 345.

Emiola, A. (2008). Nigeria Labour Law (4th ed.). Benin-City: Amfitop.

Employment Rights Act (ERA) (1996). Employment Rights Act of Britain, Section 235(5).

Erugo, S. (2019). Introduction to Nigerian Labour Law Contract of Employment and Labour Practice (2nd ed.). Lagos: Princeton \& Associates Publishing Co. Ltd.

Garner, B. A. (2004). Black's Law Dictionary (9th ed.). Eagan, MN: West Publishing Co.

Gernigon, B., Odero, A., \& Guido, H. (1998). ILO Principles Concerning the Right to Strike. International Labour Review, 137, 441-463.

Hepple, B., \& Freeman, S. (1992). Labour Law and Industrial Relations in Great Britain (pp. 474-475). Oxford: Hart Publishing.

Honeyball, S., \& Bowers, J. (2014). Textbook on Employment Law (p. 221). Oxford: Ox- 
ford University Press. https://doi.org/10.1093/he/9780199685622.001.0001

Idubor, R. (1999). Employment and Trade Dispute Law in Nigeria. Benin City: AMBIK Press.

International Covenant on Economic, Social and Cultural Rights (ICESCR), 1966.

International Labour Conference (ILC) (1983). 69th Session, Freedom of Association and Collective Bargaining: General Survey by the Committee of Experts Report 111 (4b), Paragraph 200. Geneva.

International Labour Organisation (ILO) (1957). Record of Proceedings. International Labour Conference, 40th Session, 1947. Geneva.

International Labour Organisation (ILO) (1960a). Convention No. 87, Ratified in Nigeria on the 17th of September, 1960.

International Labour Organisation (ILO) (1960b). Report No. 44, Case No. 202 Para. 137.

International Labour Organisation (ILO) (1970). Record of Proceedings. International Labour Conference, 54th Session, 1970. Geneva.

International Labour Organisation (ILO) (1985). Freedom of Association Digest. Paragraph 200.

International Labour Organisation (ILO) (1998). Record of Proceedings. International Labour Conference, 86th Session, 1998. Geneva.

International Labour Organisation (ILO) (1999). Freedom of Association: An Annotated Bibliography, 51. Geneva.

Iyabo, L. (2019). Much Ado about Non Academic Staffs Earned Allowance. https://m.guardian.ng/features/education/much-ado-about-non-academic-staffs-earne d-allowance

Khan-Freund, O., \& Hepple, B. A. (1972). Law against Strike. Fabian Research Series 305, London: Fabian Research Services.

Labour Act of Ghana (Act 651) 2003.

Labour Relations Act (LRA) (2002). Act 66 of 1995 (as Amended by the Labour Relations Amendment Act 2002) of South Africa.

Nwabueze, B. O. (1993). Military Rule and Social Justice in Nigeria (p. 152). Ibadan: Spectrum Publishers.

Okene, O. V. C. (2007). The Right of Workers to Strike in a Democratic Society. The Case of Nigeria. Sri Lanka Journal of International Law, 17, 193-221.

Orifowomo, O. A. (2004). An Appraisal of the Right to Strike under Nigerian Labour Laws. Ife Juris Law Review, 1, 380-391.

Oshio, P. E. (1996). The Bank Customer, Bank Strikes and the Law in Nigeria. In E. Chianu (Ed.), Legal Essays in Honour of Professor Sagay (pp. 171-183). Benin: Department of Public Law, University of Benin.

Otobo, D. (1987). Strikes and Lockouts in Nigeria: Some Theoretical Notes. In D. Otobo, \& O. Omole (Eds.), Readings in Industrial Relations in Nigeria (pp. 229-231). Benin City: Malthouse Press.

Padmore, G. (1945). The Voice of Coloured Labour Speeches and Reports of Colonial Delegates to the World Trade Union Conference 1945.

Romer, J. (1984). Ancient Lives: The Story of the Pharaoh's Tomb-Makers (pp. 116-123). London: Phoenix Press.

Rookes v Barnard (1963). 1 QB 623.

Schmidt and Dahlstorm v. Sweden (1980). 1 EHRR 637. 
Sheldon, L. (1992). Freedom of Association: A Study in Labour Law and Political Theory (p. 182). New Haven, CT: Yale University Press.

Shell, R. G. (2006). Bargaining for Advantage Negotiation Strategies for Reasonable People. https://www.penguinrandomhouse.com

South Africa Bill of Rights 1993.

South African Labour Relations Act, 66 of 1995.

The Eight Fundamental Conventions. Forced Labour Convention, 1930 (No. 29), Abolition of Forced Labour Convention, 1957 (105), Freedom of Association and Protection of the Right to Organize Convention, 1948 (87), Right to Organize and Collective Bargaining Convention, 1949 (No. 98), Equal Remuneration Convention, 1951 (100), Discrimination (Employment and Occupation) Convention, 1958 (111), Minimum Age convention, 1973 (138) and Worst Forms of Child Labour convention, 1999 (182).

The Labour Act of Ghana 2003.

Trade Disputes (Essential Services) Act, 1976.

Trade Disputes Act (TDA) (2004). Cap. T8 Laws of the Federation of Nigeria 2004.

Tramp Shipping Corporation v. Greenwich Marine Inc. (1975). 2 ALL E.R. 989, 991-992.

Ukhuegbe, S. O. (1996). The Right to Strike in Nigeria: A Perspective from International and Comparative. In A. Lawin Guobadia, \& S. Ukhuegbe (Eds.), Selected Essays in Law, Faculty of Law (pp. 148-149). Benin-City: University of Benin.

Union Bank of Nigeria Plc v. Edet (1993). 4 Nigerian Weekly Law Reports. Pt. 287, 288.

Uvieghara, E. E. (2001). Labour Law in Nigeria 446. Lagos: Malthouse Press Limited.

Webster, W. B. (1993). Webster's Dictionary of English Language, Deluxe Edition. Chicago, IL: Ferguson Publishing Co.

Worugji, I., \& Archibong, J. A. (2009). The Repressive Face of Law to Strike in Nigeria: Hope for Industrial Peace. Journal of Commonwealth Law and Legal Education, 7, 101-120. https://doi.org/10.1080/14760401.2009.496609 